\title{
ESTUDO DE EFICÁCIA DE SOLUÇÕES PARA ATENUAÇÃO DE RUÍDO EM INSTALAÇÕES HIDROSSANITÁRIAS.
}

\author{
KELLY RAMOS DE LIMA \\ Mestre em Habitação e Engenheira Civil \\ IPT Instituto de Pesquisa e Tecnologia de São Paulo \\ São Paulo; Brasil \\ eng.kellyramos@gmail.com
}

\section{RESUMO}

Tendo em vista os ruídos gerados pelas tubulações hidrossanitárias no interior de edificações, verificou-se qual material é mais eficaz para o isolamento acústico, aumentando a redução do nível de ruído das instalações. Para tal, analisa-se os sistemas de isolamento acústico utilizados em tubulações de esgoto de Policloreto de Vinila (PVC), por meio de um estudo comparativo dos materiais existentes no mercado. Os experimentos foram feitos em edificações na Cidade de São Paulo, simulando de forma prática, a aplicação dos materiais com características distintas. Os resultados obtidos nos ensaios permitem uma comparação da eficiência entre os métodos e materiais empregados para redução da propagação de ruídos de tubulações, tendo como referência o nível de ruído das mesmas tubulações sem envelopamento. As soluções encontradas apresentam atenuações dos ruídos gerados pelas tubulações hidrossanitárias que atendam ao desempenho mínimo determinado pela norma 15575-6 (ABNT, 2013)

Palavras-chave: Acústica de edificações. Hidrossanitário. Isolamento acústico. Ruídos. Tubulações.

\begin{abstract}
Considering noises generated by sanitary installations in buildings interior, one aims to verify, among solutions usually adopted by the sector, nowadays, which material is most efficient for acoustic insulation, increasing reduction of noise level of these installations, while meeting national rules that regard the subject. In order to achieve these purposes, one analyses acoustic insulation systems used in Poly Vinyl Chloride (PVC) sewage pipes, by means of a comparative study of materials used in buildings. The experiments were performed in high-standard buildings in the City of São Paulo so as to simulate, in a practical way, the application of different methods in materials with distinctive properties. This field research was made based on a bibliographic survey where there were identified technical rules, academic papers and journals regarding the subject. The results obtained by the essays allow comparing the efficiency among the employed methods for reduction and spreading of sewage pipes noise, taking as reference the noise level in the same pipes without acoustic protection. It was also possible to identify which solutions present bigger reduction of noise generated by sanitary pipes at rooms contiguous to bathrooms and, consequently, comply to the minimum performance determined by rule number 15575-6 (ABNT, 2013).
\end{abstract}

Keywords: Acoustic in buildings. Sanitary installation. Acoustic insulation. Noise. Pipes.

\section{INTRODUÇÃO}

Os ruídos gerados no interior das edificações podem ser ocasionados por diversos fatores. O presente estudo trata de ruídos ocasionados pelas instalações hidrossanitárias $(\mathrm{IH})$, particularmente os relativos ao acionamento das descargas de vasos sanitários, abordando-se as formas de tratamento existentes no mercado e as alternativas para se minimizar o incômodo ao usuário final.

Nas edificações, os ruídos vêm se tornando fonte de preocupação, e é necessário que se possa assegurar um isolamento acústico satisfatório tanto para os elementos estruturais quanto para qualquer tipo de som produzido pelo homem, como impactos gerados por seus objetos ou por seu convívio com outros indivíduos em sua Unidade autônoma, de forma que haja um limite de saída de sons para ambientes externos. O bom desempenho acústico de uma edificação é um dos itens relevantes para se obter condições satisfatórias de conforto para seus ocupantes e, em casos extremos, evitar a ocorrência de efeitos nocivos à saúde do ser humano. 
Com o avanço constante da construção, os apartamentos, ou residências unifamiliares, estão ficando cada vez mais confortáveis, com tecnologia, equipamentos eletrônicos de áudio e vídeo, home theaters, propiciando ambientes que necessitam de mais cuidados, para impedir a passagem de ruídos para o meio externo.

Entretanto, não obstante todas as atualizações e tecnologias envolvidas, as instalações hidrossanitárias (IH) estão presentes em todos os tipos de construção, sendo, muitas vezes, fonte de sons incômodos. Com isso, a preocupação com o isolamento das tubulações hidráulicas e suas conexões vem se tornando primordial, até porque os tubos de quedas apresentam, hoje, grandes dimensões e transportam maiores vazões, fazendo com que seja necessário garantir que os sons não ultrapassem as paredes ou lajes de cada unidade, para assegurar tranquilidade, conforto acústico e privacidade aos moradores.

Os ruídos são provenientes do recalque para os reservatórios superiores, de vibrações no sistema de recalque, do escoamento de água nas conexões curvas, de cotovelos, registros e válvulas de descarga, além do escoamento da água das louças instaladas nos banheiros, como cubas e banheiras. Os ruídos gerados pelas instalações hidrossanitárias devem se restringir apenas ao ambiente em que ele se origina, não podendo ultrapassar paredes, lajes ou forros para unidades vizinhas ou até mesmo para outros ambientes da própria unidade.

Os ensaios foram realizados em apartamentos de alto padrão, na Cidade de São Paulo, com áreas de $430 \mathrm{~m}^{2}$ e $830 \mathrm{~m}$, respectivamente. Esses ensaios foram realizados em tubulações hidráulicas de PVC, destinadas ao esgoto sanitário, revestidas com materiais disponíveis no mercado, normalmente recomendados pelos consultores e projetistas, obedecendo a critérios de envelopamento determinados pelos respectivos fabricantes e pela própria autora, com base em sua experiência profissional.

Serão apresentados os resultados dos ensaios efetuados, em análise comparativa com os de ensaios de campo. Os ruídos nas tubulações foram medidos com e sem a aplicação dos revestimentos anteriormente citados, tendo sido feita uma análise comparativa dos resultados obtidos.

Sendo assim o isolamento acústico, de fato, é essencial para preservar a vida particular dos usuários de espaços contíguos, a intimidade das famílias, e garantir que os indivíduos consigam exercer, em suas unidades, atividades rotineiras sem incomodar os vizinhos, de forma que prevaleçam a paz e o bom convívio. Todas as precauções em relação ao bom desempenho acústico de uma edificação devem ser pensadas já na concepção do projeto, visando o conforto dos futuros usuários em cada ambiente ou espaço da construção.

A metodologia geral é tratada delineando os procedimentos adotados na execução dos ensaios realizados em dois apartamentos distintos, fundamentados nas normas NBR 15575 (ABNT, 2013) e ISO 16032 (ISO, 2004) que estabelecem critérios de desempenho e métodos adequados de avaliação.

Os ensaios de campo, inclui descrições das unidades, plantas, fotografias, além dos materiais empregados e procedimentos utilizados para envelopamento.

Os resultados encontrados nos ensaios são analisados, por intermédio de tabelas e gráficos comparativos, onde estão tabulados os valores obtidos em cada uma das medições feitas nos ambientes receptores dos ensaios.

\section{RUIIDO EM INSTALAÇÕES HIDROSSANITÁRIAS E SEUS MÉTODOS DE CONTROLE}

Serão analisados os ruídos em instalações hidrossanitárias, detalhando tipos de geração e formas de transmissão, embasado nos ensaios e análises da autora. Ainda serão, determinados métodos de envelopamento existentes no mercado nacional, com descrições de procedimentos adotados na Construção Civil, delineando os procedimentos adotados na execução dos ensaios realizados em dois apartamentos distintos, fundamentados nas normas NBR 15575 (ABNT, 2013), a norma 10152 (ABNT, 2017) e ISO 16032 (ISO, 2004) que estabelecem critérios de desempenho e métodos adequados de avaliação.

\subsection{Acústica - Considerações Gerais}


A Acústica é a ciência dedicada ao estudo do som e a suas inter-relações com o ser humano, conforme descrito por Mateus (2008), sendo que a propagação desse pode ser através do meio gasoso, líquido ou sólido. O som pode ser definido como qualquer variação de pressão atmosférica que o ouvido humano possa capturar, conforme mostrado na Figura 1.

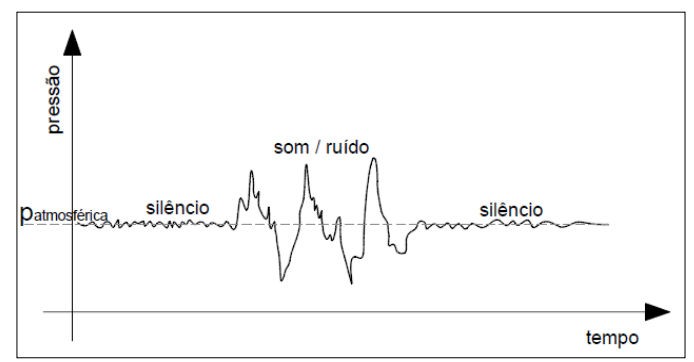

Figura 1 - Variação de pressão produzida por uma fonte sonora (Fonte: Mateus/2008)

Mateus (2008) ainda comenta que a diferença entre som e ruído é subjetiva, não dependendo apenas de sua frequência e de sua amplitude, sendo, no entanto, o som associado às sensações de variação de pressão audível (como quando se ouve uma música ou a voz humana), e o ruído associado às sensações desagradáveis e indesejáveis.

\subsection{Ruído em Edificações}

\subsubsection{Fontes de Ruídos}

Pode-se considerar que são diversas as fontes de ruídos em uma edificação. Alguns ruídos são de origem externa, como aquele produzido pelo tráfego de veículos automotores, trens e aviões. Outros podem ser gerados por equipamentos coletivos existentes no próprio interior das edificações. Tais ruídos podem ser transmitidos pela estrutura e paredes divisórias, quando, por exemplo, ocorre a movimentação de elevadores; há o acionamento de bombas; usuários caminham; objetos caem; móveis são arrastados. Como também os ruídos gerados pelas instalações hidrossanitárias (IH) embutidas na alvenaria, sob as lajes e em shafts.

Um edifício deve ser projetado seguindo diretrizes básicas de uma boa construção e suas respectivas especificações, subdivididas em grupos básicos, sendo que uma delas é o conforto acústico, segundo a ISO (International Organization for Standardization) nº 6241 (1982), e a Norma de Desempenho nº 15575-6 (ABNT, 2013).

O desempenho acústico conforme requisitos determinados na norma NBR 15575-6 (ABNT, 2013), estabelece um método de medição dos ruídos gerados por equipamentos prediais, apresentando valores descritos na Tabela 2 , que mostra os níveis de desempenho. Todas as instalações operando devem atender aos critérios estabelecidos nessa tabela.

Tabela 2 - Valores do $L_{A e q, n T}$ medidos em dormitórios

\begin{tabular}{|c|c|}
\hline $\begin{array}{c}L A_{e q, n T} \\
\mathrm{~dB}(\mathrm{~A})\end{array}$ & Nível de desempenho \\
\hline$\leq 30$ & $\mathrm{~S}$ (Superior) \\
\hline$\leq 34$ & I (Intermediário) \\
\hline$\leq 37$ & $\mathrm{M}$ (Mínimo) \\
\hline
\end{tabular}

Fonte: Adaptado da norma NBR 15575-6 (ABNT, 2013)

O desempenho acústico mínimo de um aparelho sanitário como, por exemplo, o lavatório, pode ser especificado na

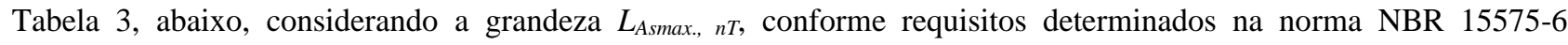
(ABNT, 2013).

Tabela 3 - Valores máximos do nível de pressão sonora máximo $L_{A s m a x ., n} T$, medido em dormitórios

\begin{tabular}{|c|c|}
\hline $\begin{array}{c}L_{\text {Asmax.,nT. }} \\
\mathrm{dB}(\mathrm{A})\end{array}$ & Nível de desempenho \\
\hline$\leq 36$ & S (Superior) \\
\hline$\leq 39$ & I (Intermediário) \\
\hline$\leq 42$ & M (Mínimo) \\
\hline
\end{tabular}

Fonte: Adaptado da norma NBR 15575-6 (ABNT, 2013) 
Para medir o desempenho acústico das instalações hidrossanitárias, devem ser realizados ensaios na peça em que ocorre o ruído quando do acionamento do equipamento (ruído emitido), seja ela contígua ao banheiro em que o equipamento está instalado, ou esteja acima ou abaixo do mesmo.

Deve ser verificado o nível de ruído máximo no ambiente interno, com equipamento fora de operação $\mathrm{L}_{\text {Aai }}$, no momento da medição. Caso o valor seja maior que o determinado nos parâmetros acústicos de verificação - Valores do L $\mathrm{L}_{\mathrm{Aeq}}$, nT medidos em dormitórios - o ensaio deverá ser realizado em um horário mais silencioso para que seja possível a medição.

Nomenclatura para os parametros acústicos de verificação:

- $\quad L_{A e q, n T}$ :Nível de pressão sonora equivalente, padronizado de equipamento predial

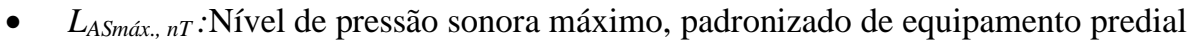

- $\quad L_{A a i}$ : Nível de pressão sonora equivalente no ambiente interno, com equipamento fora de operação

Ainda determinado na norma NBR 15575-6 (ABNT, 2013), deve ser obtido o nível de pressão sonora contínua, equivalente, padronizada de um ciclo de operação do equipamento predial, $\mathrm{L}_{\text {Aeq,nT, }}$ e o nível de pressão sonora máximo, $\mathrm{L}_{\mathrm{ASmax}, \mathrm{nT}}$ do ruído gerado pela operação do equipamento. O ciclo de operação do produto deve atender aos critérios especificados na norma brasileira de cada produto.

Na Figura 1, pode-se verificar um corte esquemático, demonstrando os ruídos gerados por equipamentos prediais, onde encontram-se o aparelho emissor e o ambiente receptor.

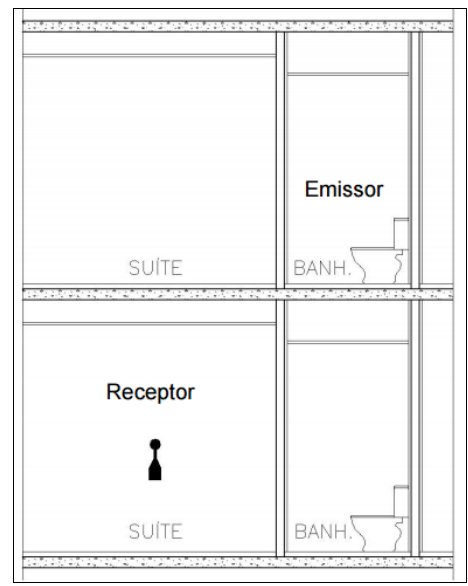

Figura 1 - Ruídos gerados por equipamentos prediais (corte esquemático para ensaio de campo) Fonte: Instituto de Engenharia de São Paulo - Divisão de Acústica (2014)

\subsection{Tipos de ruídos}

Os diferentes tipos de ruídos são descritos abaixo, conforme adaptação da Associação Brasileira para a Qualidade Acústica (PIERRARD, AKKERMAN, 2013) e Mateus (2008), sendo classificados em:

a) ruído aéreo - transmissão de ruído entre duas Unidades habitacionais sobrepostas em uma edificação. Esse se produz através do próprio piso, elementos laterais ou paredes. O desempenho de isolamento de ruído aéreo deve ser obtido por meio de uma adequada execução nas paredes e piso, evitando frestas que permitam a passagem do ruído (PIERRARD, AKKERMAN, 2013);

b) ruído de impacto - transmissão de ruído entre duas Unidades habitacionais sobrepostas em uma edificação, que se produz através do próprio sistema de piso. Essa transmissão depende das propriedades das soluções construtivas, considerando, dessa forma, o desempenho de isolamento ao ruído de impacto entre dois ambientes (PIERRARD, AKKERMAN, 2013);

c) ruído de equipamento - sons provenientes de equipamentos de uso coletivo em uma edificação, como bombas de recalque e circulação, ventilação mecânica, aquecedores de água, elevadores e portões de garagem, entre outros, que são transmitidos por via aérea e estrutural (PIERRARD, AKKERMAN, 2013); 
d) ruído contínuo equivalente - nível sonoro que corresponde ao valor único que tem a mesma energia sonora da globalidade do ruído, não uniforme, mantendo-se no mesmo intervalo de medição. A partir desse nível sonoro são determinados parâmetros para exposição dos trabalhadores ao ruído e, ainda, indicadores de ruídos ambientais (MATEUS, 2008).

Conforme Bataglin (2014), a Parte 6 da norma ABNT NBR 15575 (2013), denominada "Requisitos para os Sistemas Hidrossanitários", determina como devem ser os sistemas prediais de água fria e água quente, assim como o sistema de esgoto sanitário e a ventilação, contemplando ainda os sistemas de águas pluviais. Ainda de acordo com o mesmo autor, os sistemas hidrossanitários devem resistir às solicitações mecânicas e dinâmicas, e não devem provocar golpes e vibrações no sistema hidráulico que impliquem risco à sua estabilidade estrutural.

O conforto acústico de uma edificação, tem como prioridade preservar a individualidade os ocupantes, tanto para unidades vizinhas como para o ambiente interno da unidade privativa, alem de promover um ambiente agradável para o seu descanso em horários noturnos.

\section{METODO DE TRABALHO}

Os ensaios foram realizados em dois edifícios no Bairro Jardim Europa, São Paulo, Capital, com as mesmas características arquitetônicas de estilo neoclássico e considerados edifícios de alto padrão, sendo que o edifício do Ensaio A (Edifício 1) é constituído por 2 torres com 32 pavimentos, cobertura e barrilete, além de 4 subsolos e térreo interligados. O edifício do Ensaio B (Edifício 2), consiste em 1 torre com 20 pavimentos, cobertura e barrilete, além de 4 subsolos e térreo.

\subsection{Descrições dos Materiais de Isolamento Acústico}

As tubulações das instalações hidrossanitárias das Unidades ensaiadas consistem em tubos de PVC, conexões e ralos sifonados.

Os materiais utilizados para proteger as tubulações das instalações hidrossanitárias das Unidades ensaiadas, localizadas nas Unidades do Ensaio A - $16^{\circ}$ andar e $17^{\circ}$ andar/Edifício 1 e no Ensaio B - $7^{\circ}$ andar e $8^{\circ}$ andar/Edifício 2, são:

a) material 1 - Manta de feltro aerado termoacústica com espessura $10 \mathrm{~mm}$, composta de $85 \%$ de fibras têxteis de Pet reciclado e $15 \%$ de fibras têxteis de copoliéster, produto $100 \%$ reciclável;

b) material 2 - Manta isolante borracha com espessura 2,6 mm, composta de mistura EPDM $^{1}$ e de grânulos de pneus reciclados (borracha $\mathrm{SBR}^{2}$ ), aglomerada e laminada, com densidade de $1200 \mathrm{~kg} / \mathrm{m}^{3}$;

c) material 3 - Acabamento para ralo sifonado com espessura $12 \mathrm{~mm}$, composto da mistura de EPDM e de grânulos de pneus reciclados (borracha SBR), aglomerada e prensada, com densidade de 1000 a $1200 \mathrm{~kg} / \mathrm{m}^{3}$;

d) material 4 - Manta asfáltica estruturada em não tecido de fibra de vidro, produzida com asfalto especial com espessura de $3 \mathrm{~mm}$, acoplada com geotêxtil de alta gramatura, com densidade de $800 \mathrm{~kg} / \mathrm{m}^{3}$;

a) material 5 - Tubo bipartido em lã de rocha de alta intensidade, aglomerados com resinas especiais, com espessura de $50 \mathrm{~mm}$ e densidade de 120 a $150 \mathrm{~kg} / \mathrm{m}^{3}$;

b) material 6 - Lençol de borracha natural de $6,4 \mathrm{~mm}$, com dureza da borracha em 70 +/- Shore A;

c) material 7 - Abraçadeira Q-tie de nylon com comprimento de $210 \mathrm{~mm}$ e largura 4,7 mm referência Q50R.

Os materiais descritos acima foram utilizados nos Ensaios A e B, como apresentados na Tabela 4 a seguir:

Tabela 4 - Descrição dos materiais utilizados em cada um dos ensaios

\begin{tabular}{|l|l|l|l}
\hline Ensaio & Ambiente & Unidade & Descrição dos materiais \\
\hline
\end{tabular}




\begin{tabular}{|c|c|c|c|}
\hline A & Banheiro 1 & $16^{\circ}$ andar $-161 \mathrm{~B}$ & $\begin{array}{l}1^{\mathrm{a}} \text { camada: material } 1-\text { manta de feltro termoacústico com } 10 \mathrm{~mm} \text {; } \\
2^{\mathrm{a}} \text { camada: material } 2 \text { - manta isolante de borracha com } 2,6 \mathrm{~mm} \text {; } \\
\text { material } 3 \text { - acabamento de ralo sifonado de borracha com } 12 \mathrm{~mm} \text {. } \\
\text { Todas as camadas fixadas com abraçadeira Q-tie de nylon } \\
\text { (material 7). }\end{array}$ \\
\hline A & $\begin{array}{l}\text { Banheiro } 3 \text { e } \\
\quad \text { Suíte } 3\end{array}$ & $16^{\circ}$ andar $-161 \mathrm{~B}$ & $\begin{array}{l}1^{\mathrm{a}} \text { camada: material } 1-\text { Feltro termoacústico com } 10 \mathrm{~mm} \text {; } \\
2^{\mathrm{a}} \text { camada: material } 2 \text { - manta isolante de borracha com } 2,6 \mathrm{~mm} \text {; } \\
\text { material } 3 \text { - acabamento de ralo sifonado de borracha com } 12 \mathrm{~mm} \text {. } \\
\text { Todas as camadas fixadas com abraçadeira Q-tie de nylon } \\
\text { (material 7). }\end{array}$ \\
\hline B & $\begin{array}{l}\text { Banheiro } \\
\text { Hóspede }\end{array}$ & $7^{\circ}$ andar -71 & $\begin{array}{l}1^{\mathrm{a}} \text { camada: material } 5 \text { - tubo bipartido de lã de rocha com } 50 \mathrm{~mm} \text {; } \\
2^{\mathrm{a}} \text { camada: material } 6 \text { - lençol de borracha com } 6,4 \mathrm{~mm} . \\
\text { Todas as camadas fixadas com abraçadeira Q-tie de nylon } \\
\text { (material 7). }\end{array}$ \\
\hline B & $\begin{array}{l}\text { Banheiro } \\
\text { Hóspede }\end{array}$ & $7^{\circ}$ andar -71 & $\begin{array}{l}\text { Camada única: material } 5 \text { - manta asfáltica acoplada com geotêxtil } \\
\text { com } 3 \mathrm{~mm} \text {. } \\
\text { Camada fixada com abraçadeira Q-tie de nylon (material 7) }\end{array}$ \\
\hline A e B & & & $\begin{array}{l}\text { Em ambos foram efetuados ensaios nas tubulações de PVC sem } \\
\text { revestimento. }\end{array}$ \\
\hline
\end{tabular}

3.2 Descrição do Método de Medição (Ensaios A e B - Procedimentos Gerais)

\subsubsection{Metodologia dos Ensaios A e B}

A metodologia adotada para a realização dos ensaios de campo, suas medições e resultados de laboratório, foram escolhidas para melhor determinar os resultados encontrados, considerando os ruídos de fundo, ruídos aéreos e ruído no ambiente, com equipamentos adequados especificados pela Norma ISO 16032 (ISO, 2004).

Para obedecer à metodologia, foi preciso executar as ações listadas, in loco, que foram feitas na ordem que segue:

a) medir o ruído de fundo do ambiente externo;

b) determinar quatro (4) cantos, que são as quatro (4) extremidades de um recinto P1, P2, P3 e P4;

c) acionar a válvula de descarga da caixa acoplada existente na bacia sanitária, para determinar o canto inicial, que é o canto em que há maior emissão de ruído, considerado o canto crítico (CC) ou canto principal;

d) abrir os chuveiros (duplo), para determinação da maior emissão de ruído, considerando os cantos determinados no item c;

e) depois de determinado o canto crítico, determinar mais dois cantos intermediários para o canto crítico (CC) de maior emissão de ruído;

f) demarcar dois cantos adicionais de medição, denominados, respectivamente canto 1 (PA) e canto 2 (PB), ambos tendo entre si e entre eles e os quatro cantos (corners) uma distância mínima de 0,50 metros;

g) fazer duas medições em cada canto, sendo eles o P1(CC), PA e PB, respectivamente;

h) medir a reverberação de ruído no ambiente - método de som interrompido. Com o auxílio de uma caixa dodecaédrica e um amplificador ajustado para emitir ruído rosa, foi determinado o tempo de reverberação do ruído no ambiente.

i) posicionar o microfone no campo reverberante: Foram definidas duas posições adicionais no campo de reverberação do ambiente, mantendo uma distância mínima de pelo menos 1,50 entre as posições 1 (canto principal), 2 e 3 . A distância entre os cantos 2 e 3, no ambiente foi de, no mínimo, 0,75 m. Manter a altura acima do nível do piso acabado de pelo menos 0,5 m e não mais alto que 1,5 m, descrição determinada pela ISO 16032 (ISO, 2004).

A seguir, detalhes apresentados nas Plantas 1, 2 e 3 para determinar o canto crítico e, posteriormente, os demais cantos, para início das medições de pressão sonora.

Planta 1 - Quatro (4) cantos principais do Banheiro 1 da Unidade 161B com uma área aproximada de $17 \mathrm{~m}^{2}$, para determinação do canto crítico
Planta 2 - Quatro (4) cantos principais na Suíte 3 da Unidade 161B com uma área aproximada de $18 \mathrm{~m}^{2}$, para determinação do canto crítico
Planta 3 - Banheiro Hóspede com uma área aproximada de 6 $\mathrm{m}^{2}$, com a demarcação dos quatro (4) cantos principais e cantos intermediários 

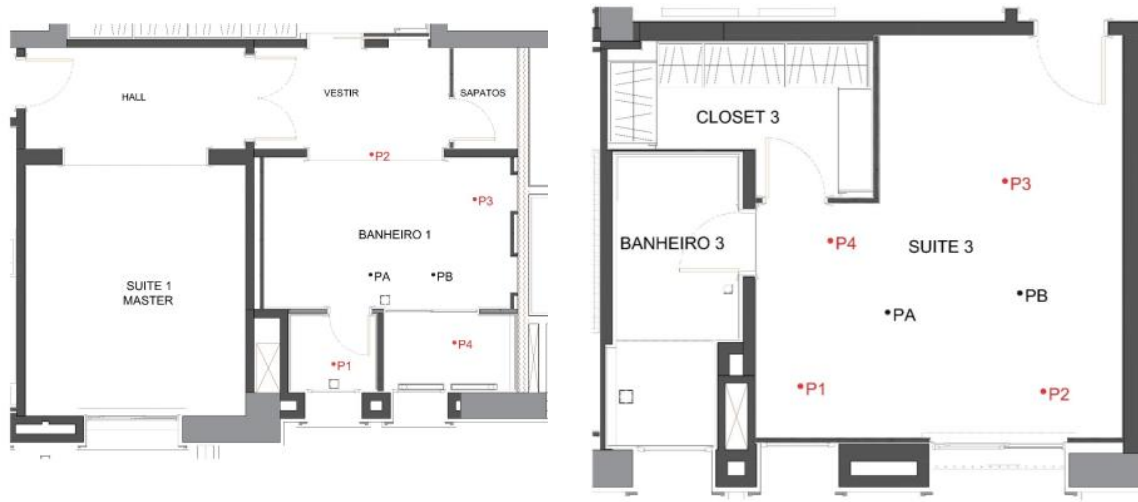

mostra os quatro cantos principais do Banheiro 1 do Ensaio A para a determinação do canto crítico mostra os quatro cantos principais da Suíte 3 do Ensaio A para determinação do canto crítico

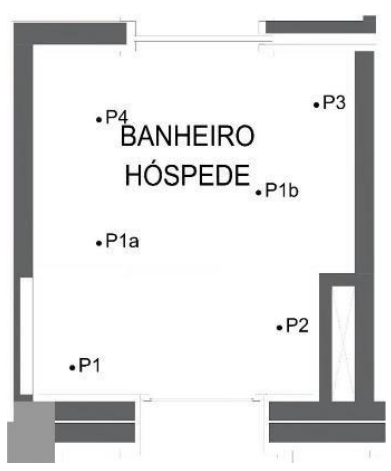

mostra os quatro cantos principais no Banheiro Hóspede do Ensaio B para determinação do canto crítico.

Os dois ensaios foram realizados em unidades receptoras que estavam em fase de obra. Isso significa, portanto, que nessas unidades não havia acabamentos finais e, o mais importante, os forros de gesso não estavam concluídos, o que foi relevante para medir os ruídos nas tubulações hidrossanitárias, sem qualquer interferência de materiais que pudessem atenuá-los.

Para o Ensaio A/Edifício 1, consistindo em medições de ruídos aéreos, os locais escolhidos foram os Banheiro 1 e Banheiros 4 e 5 existente na Unidade $171 \mathrm{~B} / 17^{\circ}$ andar. Uma vez determinados os cantos em que seriam feitas as medições, foi, em cada experimento, acionada a válvula de descarga com volume total de 6 litros da respectiva bacia sanitária com caixa acoplada e abertura de dois (2) chuveiros, no caso do Ensaio A, para assim serem efetuadas as devidas medições de ruídos aéreos.

O local escolhido para o Ensaio B/Edifício 2, consistindo em medições de ruídos aéreos, foi o Banheiro Hóspede da Unidade 71. Para o Ensaio B, consistindo em medições de ruídos aéreos, o local determinado foi o Banheiro Hóspede existente na Unidade 71.

As medições in loco foram feitas logo após o acionamento da válvula de descarga das bacias sanitárias com volume de 6 litros, ocasionando seu esvaziamento total, tanto no Ensaio A/Edifício 1, na Unidade 171B do $17^{\circ}$ andar, quanto no Ensaio B/Edifício 2, na Unidade 81 do $8^{\circ}$ andar, de forma que fosse possível obter aferir o ruído aéreo no pico. As medições foram efetuadas com as tubulações revestidas com materiais adequados para isolamento acústico de tubulações com todos os materiais descritos no item 3.1 e, também, sem o envelopamento, de maneira a possibilitar uma análise comparativa dos resultados.

Depois de feitas todas as medições de ruídos aéreos nos Ensaios A e B, com as respectivas tubulações revestidas com materiais para isolar seu ruído, assim como sem revestimento, como mencionado foram efetuadas medições do tempo de reverberação de ruído nos ambientes.

\subsubsection{Método de Análise de Dados}

Neste ensaio de campo, as medições foram feitas de acordo com a norma ISO 16032 (ISO, 2004) e norma NBR 15575 6 (ABNT, 2013), que determina que a medição não deve ser realizada quando o ruído de fundo for maior do que os mostrados na Tabela 1, que apresenta os valores do $L_{A e q, n T^{3}}$ para dormitórios, e de um lavatório, pode ser especificado na Tabela 2, considerando a grandeza $L_{A S m a x ., n T}{ }^{4}$, mencionadas anteriormentes. 
É recomendável que esses requisitos de desempenho, mesmo que apenas informativos, sejam observados, pois os ruídos de equipamentos prediais e de sistemas hidrossanitários são origem da maior parte das reclamações dos moradores de edifícios residenciais.

\section{ENSAIOS DE CAMPO}

Nos Ensaios A e B foi aferido o nível de ruído aéreo causado pelo acionamento da válvula de descarga das bacias sanitárias com caixas acopladas e, no Ensaio A, também o causado pela abertura dos registros dos chuveiros. Para os ensaios, todas as tubulações foram envelopadas com revestimentos de forma a atenuar o ruído aéreo causado pelas instalações hidrossanitárias, mais especificamente pelas tubulações de esgoto das bacias sanitárias e ralos sifonados destinados ao escoamento de fluidos; também foram efetuados ensaios para tubulações sem envelopamento.

A intenção dos ensaios, como mencionado, foi determinar quais os métodos e materiais mais favoráveis para obter níveis de atenuação desses ruídos de forma que ficassem suficientemente baixos para garantir o conforto acústico nas Unidades.

\subsection{Ensaios de Campo A e B}

\subsubsection{Descrição das Unidades $161 \mathrm{~B} / 16^{\circ}$ andar e $171 \mathrm{~B} / 17^{\circ}$ andar}

Os ensaios foram efetuados nos ambientes receptores dos ruídos, ou seja, não nos banheiros a que pertencem os acessórios e as tubulações hidrossanitárias - neste caso, os da Unidade 171B - mas, sim, nos ambientes abaixo deles, onde as tubulações hidrossanitárias foram envelopadas com materiais de isolamento acústico, ou seja, no caso do Ensaio A, no Banheiro 1, sobre o qual fica o Banheiro 1 da Unidade 171B e na Suíte 3 da Unidade 161B, sobre a qual ficam os Banheiros 4 e 5 da Unidade 171B.

Figura 2- Banheiro1 da Unidade 171B

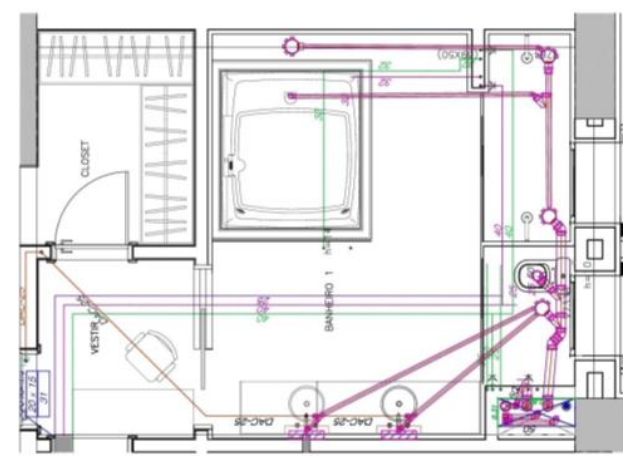

Figura 3 - Banheiros 4 e 5 da Unidade 171B

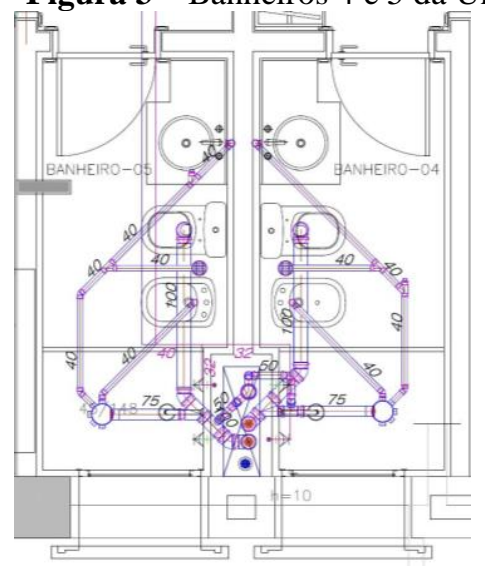

O Ensaio A, foi realizado na Unidade $161 \mathrm{~B} / 16^{\circ}$ andar do Edifício 1, denominada receptora de ruídos, ruídos esses provenientes da Unidade $171 \mathrm{~B} / 17^{\circ}$ andar, denominada geradora. As tubulações hidráulicas existentes na Unidade 161B, são da Unidade 171B.

\subsubsection{Ensaio B - Unidade Residencial no Edifício 2}

O Ensaio B foi feito em dois andares do Edifício 2, que tem apenas uma Unidade por andar, sendo que a Unidade $71 / 7^{\circ}$ andar, receptora, foi modificada, e a geradora, a Unidade $81 / 8^{\circ}$ andar, é denominada tipo. Os banheiros do Ensaio B estão nos locais mostrados nas plantas de cada Unidade, sendo que uma bacia sanitária foi instalada no Banheiro 5 do apartamento $81 / 8^{\circ}$ andar para o ensaio

As Figuras 4 e 5, mostram os locais onde foi elaborado o Ensaio B, com detalhes construtivos dos ambientes receptores, da Unidade $71 / 7^{\circ}$ andar. 
A Figura 6 detalha pavimento tipo, denominado 81/8 andar (gerador). O local em que foi instalado uma bacia sanitária com caixa acoplada, foi o Banheiro 5, localizado acima do Banheiro Hóspede da Unidade $71 / 7^{\circ}$ andar (receptor).

Figura 4 - Planta baixa da Suíte Hóspede Figura 5 - Detalhe do Banheiro Hóspede

Figura 6 - Detalhes das instalações hidráulicas do Banheiro 5.
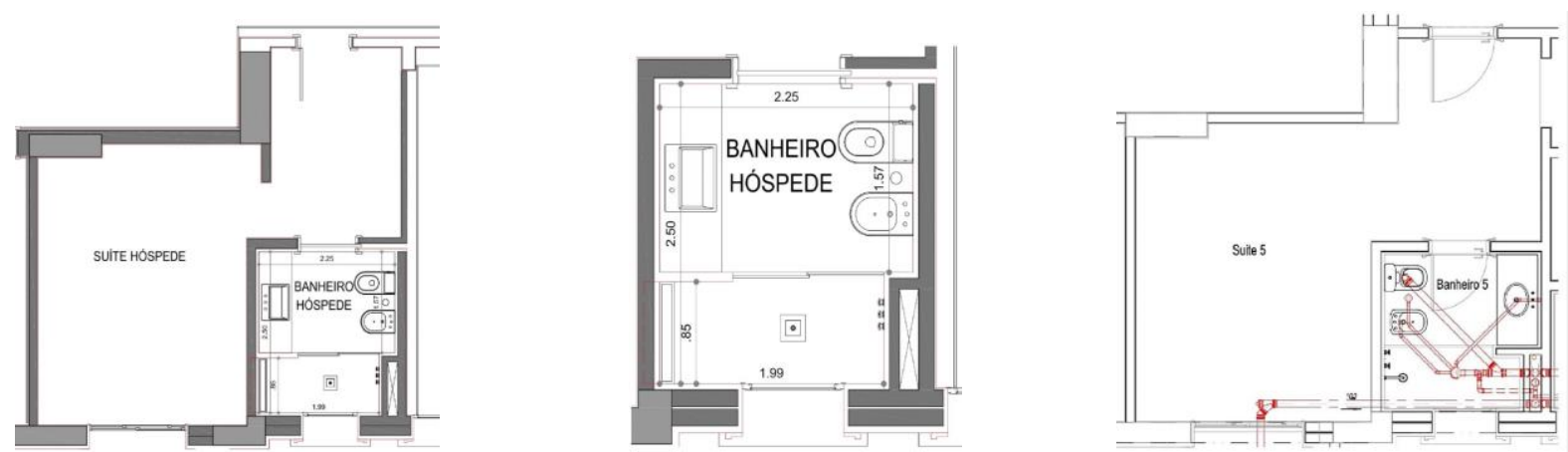

As tubulações de PVC destinadas ao esgoto da bacia sanitária receberam um envelopamento com tubo bipartido de lã de rocha com espessura de $50 \mathrm{~mm}$ (material 5), sobreposta com manta de borracha com espessura 6,4 mm (material 6). Ambas as camadas foram fixadas com abraçadeira Q-tie de nylon (material 7). Posteriormente, a tubulação de PVC foi revestida com uma manta asfáltica acoplada com geotêxtil com espessura de $3 \mathrm{~mm}$ (material 4), fixada com a abraçadeira denominada Material 7. Ambos os procedimentos foram executados com a intenção de atenuar os ruídos ocasionados pelo escoamento da água ao passar pela tubulação.

\section{RESULTADOS}

Os Ensaios A e B foram realizados com acionamento das caixas de descarga das bacias sanitárias com caixa acoplada e, no caso do Ensaio A, com a abertura das válvulas de dois (2) chuveiros, quando foram elaboradas medições, obedecendo à seguinte ordem:

a) medição de ruído das tubulações hidrossanitárias sem envelopamento;

b) medição de ruído das tubulações hidrossanitárias devidamente envelopadas com materiais 1, 2, 3, 4, 5 e 6 especificados no item 3.1 .

Para elucidar os resultados apontados graficamente, a análise comparativa dos resultados encontrados nos ambientes receptores com revestimento e sem revestimento, podendo-se visualizar mais claramente os resultados obtidos após suas respectivas tabelas (Figura 7 a 9).

Figura 7 (Gráfico) - Análise dos resultados no Banheiro 1 - 161B/16 ${ }^{\circ}$ andar, acionamento da válvula de descarga na Unidade emissora, comparando a tubulação hidrossanitária, com e sem o revestimento acústico. A faixa cinza representa a frequência de maior sensibilidade ao ouvido humano.

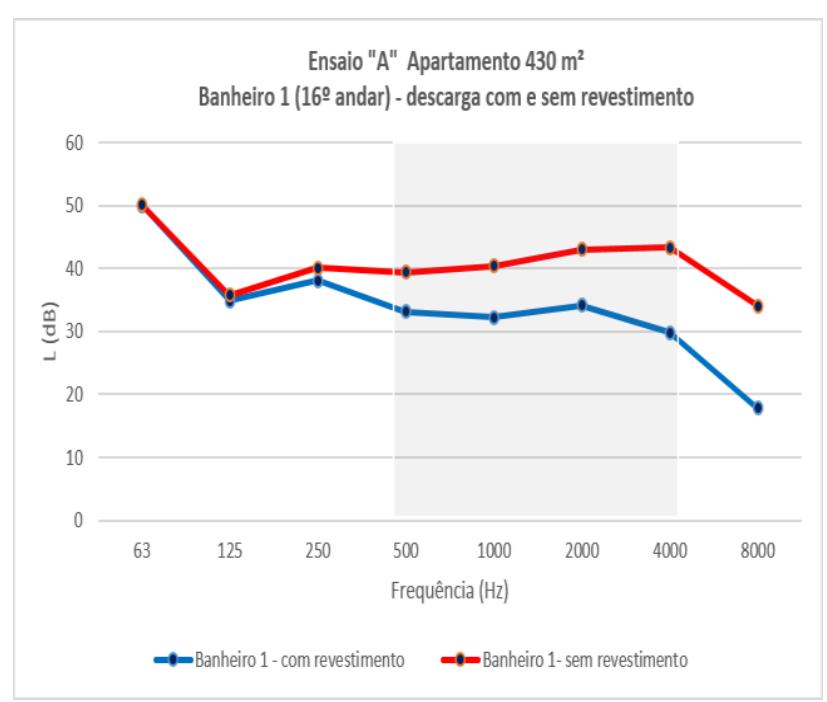


Figura 8 (Gráfico) - Análise dos resultados na Suíte 3 - 161B $/ 16^{\circ}$ andar, acionamento das válvulas de descargas (Banheiros 4 e 5) na Unidade 171B, comparando a tubulação hidrossanitária, com e sem o revestimento acústico. A faixa cinza representa a frequência de maior sensibilidade ao ouvido humano.

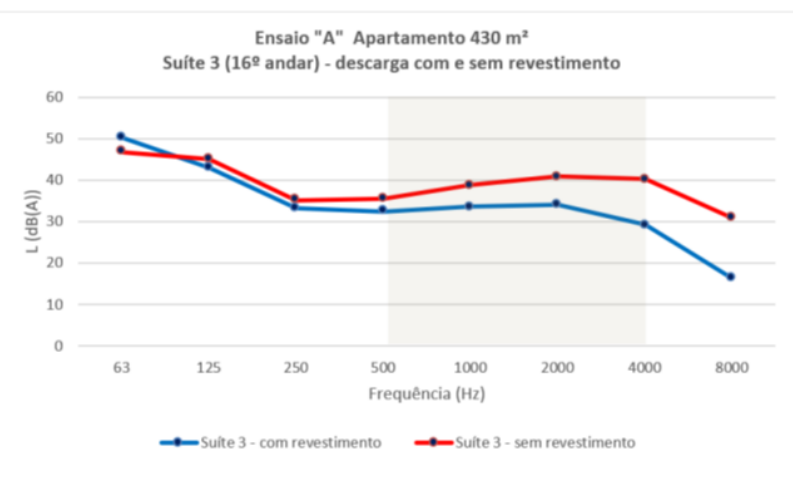

Ensaio "A" Apartamento $430 \mathrm{~m}^{2}$

Banheiro 1 (16ㅇaㅁ ar) - chuveiro com e sem revestimento

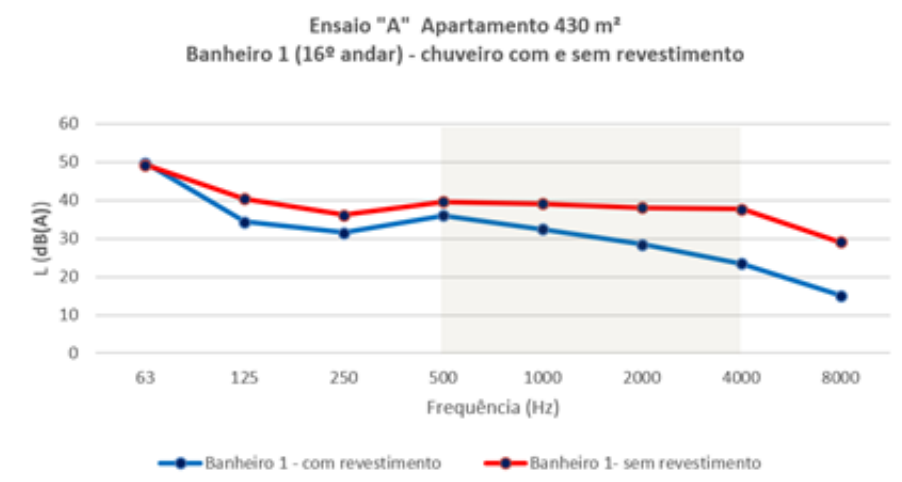

Figura 9 (Gráfico) - Análise dos resultados no Banheiro 1 - 161B/16 ${ }^{\circ}$ andar, acionamento dos chuveiros na Unidade emissora, comparando a tubulação hidrossanitária, com e sem o revestimento acústico. A faixa cinza representa a frequência de maior sensibilidade ao ouvido humano.

Para a obtenção dos parâmetros $L_{\text {Aeq,nT }}$ e $L_{A S m a x ., n T}$, foram feitas medições atendendo a todos os critérios determinados pela ISO 16032 (ISO, 2004), como indicado nas Tabelas 5 e 6 e nos Gráficos acima:

Tabela 5 - Resumo dos resultados de $L_{A e q, n T}$ e $L_{A S m a x ., n T}$, encontrados nos resultados das medições sonoras, para tubulação de PVC sem revestimento

\begin{tabular}{|c|c|c|c|c|c|c|}
\hline \multicolumn{2}{|c|}{ Andares/Unidades } & \multirow{2}{*}{$\begin{array}{l}\text { Emissor de } \\
\text { ruído }\end{array}$} & \multicolumn{2}{|c|}{ Ambientes } & \multicolumn{2}{|c|}{$\begin{array}{c}\text { Resultados sem } \\
\text { revestimento } \mathrm{dB}(\mathrm{A})\end{array}$} \\
\hline Emissor & Receptor & & Emissores & Receptores & $L_{\text {Aeq, } n T}$ & $L_{A S \max , n T}$ \\
\hline \multirow{3}{*}{$\begin{array}{c}17^{\circ} \text { andar } \\
171 \mathrm{~B}\end{array}$} & \multirow{3}{*}{$\begin{array}{c}16^{\circ} \text { andar } \\
161 \mathrm{~B}\end{array}$} & Descarga & Banheiro 1 & Banheiro 1 & 49 & 51 \\
\hline & & Descargas & Banheiro 4 e 5 & Suíte 3 & 46 & 49 \\
\hline & & Chuveiros & Banheiro 1 & Banheiro 1 & 45 & 47 \\
\hline
\end{tabular}

Figura 10 (Gráfico) - Análise dos resultados no Banheiro 1 e na Suíte 3, 161B para $L_{A e q, n T}$ e $L_{A S \max , n T}$, encontrados nos resultados das medições sonoras de tubulação de PVC sem revestimento

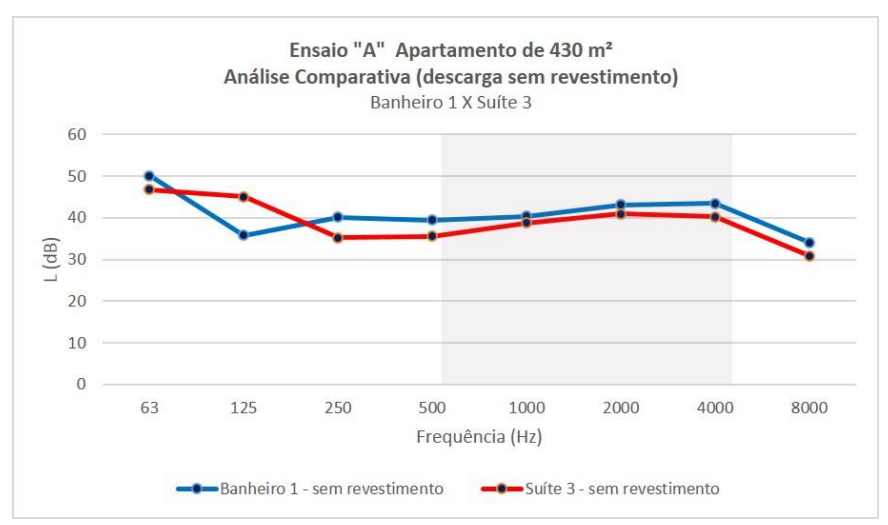


Figura 11 (Gráfico) - Análise dos resultados no Banheiro 1 e na Suíte $3,161 \mathrm{~B} / 16^{\circ}$ andar para $L_{A e q, n T}$ e $L_{A S m a x, n T}$, encontrados nos resultados das medições sonoras de tubulação de PVC com revestimento
Figura 12 (Gráfico) - O resultado encontrado na medição do ruído ocasionado pelo escoamento de água dos chuveiros, no Banheiro 1 (receptor), é de $37 \mathrm{~dB}(\mathrm{~A})$ para $L_{\text {Aeq }}$, atendendo perfeitamente ao desempenho mínimo exigido pela norma em vigor
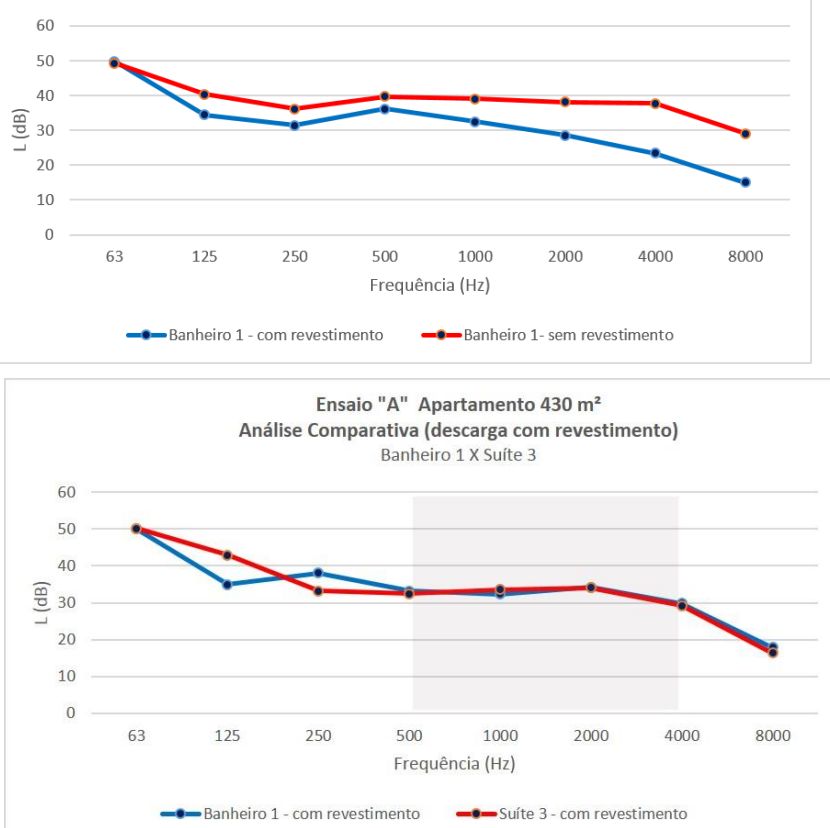

Tabela 6 - Resumo dos resultados de $L_{A e q, n T}$ e $L_{A S m a x, n T}$, encontrados nos resultados das medições sonoras de tubulação de PVC com revestimento

\begin{tabular}{|c|c|c|c|c|c|c|}
\hline \multicolumn{2}{|c|}{ Andares/Unidades } & \multirow{2}{*}{$\begin{array}{l}\text { Emissor de } \\
\text { ruído }\end{array}$} & \multicolumn{2}{|c|}{ Ambientes } & \multicolumn{2}{|c|}{$\begin{array}{c}\text { Resultados com } \\
\text { revestimento } \mathrm{dB}(\mathrm{A})\end{array}$} \\
\hline Emissor & Receptor & & Emissores & Receptores & $L_{\text {Aeq, } n T}$ & $L_{A S \max ., n T}$ \\
\hline \multirow{3}{*}{$\begin{array}{c}17^{\circ} \text { andar } \\
171 \mathrm{~B}\end{array}$} & \multirow{3}{*}{$\begin{array}{c}16^{\circ} \text { andar } \\
161 \mathrm{~B}\end{array}$} & Descarga & Banheiro 1 & Banheiro 1 & 39 & 42 \\
\hline & & Descargas & Banheiro 4 e 5 & Suíte 3 & 39 & 42 \\
\hline & & Chuveiros & Banheiro 1 & Banheiro 1 & 37 & 38 \\
\hline
\end{tabular}

Os resultados encontrados nos ambientes receptores denominados Banheiro 1 e Suíte 3, com $L_{\text {Aeq,nT }}$ de 39 dB(A) apontam uma diferença de $2 \mathrm{~dB}(\mathrm{~A})$, para chegar ao desempenho mínimo, considerando que as tubulações estavam totalmente livres de qualquer outro tipo de revestimento como forro de gesso ou paredes de divisa. Os resultados do $L_{A S m a x}$, em todos os ensaios realizados, tanto das válvulas de descarga quanto do escoamento de água dos chuveiros, atendem perfeitamente ao desempenho mínimo exigido pela norma 15575-6 (ABNT, 2013). Os resultados encontrados nos ensaios B feitos com os materiais 5 e 6, apresentam uma maior atenuação do ruído nas altas frequências do que nas baixas. Já o material 4 apresenta uma melhora na atenuação do ruído nas baixas frequências, conforme pode ser visualizado nos Gráficos 7 e 8 apresentados a seguir.

Figura 13 (Gráfico) - Análise dos resultados no Banheiro Hóspede da Unidade $71 / 7^{\circ}$ andar com acionamento da válvula de descarga na Unidade emissora. Comparação do ruído da tubulação hidrossanitária com e sem revestimento acústico.

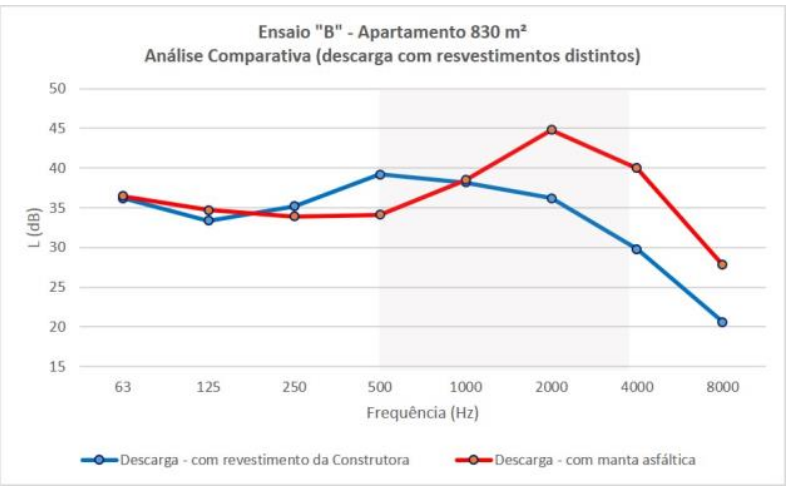

Figura 14 (Gráfico) - Análise dos resultados no Banheiro Hóspede da Unidade $71 / 7^{\circ}$ andar do acionamento da válvula de descarga na Unidade emissora, comparando a tubulação hidrossanitária, com revestimentos distintos.

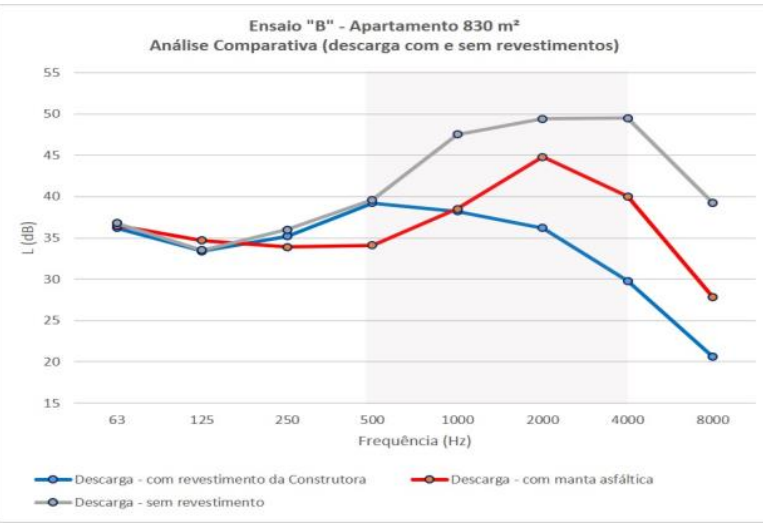


Tabela 7 - Resumo dos resultados de $L_{A e q, n T}$ e $L_{A S m a x, n}$, encontrados nas medições sonoras, para tubulação de PVC com revestimentos diferentes.

\begin{tabular}{|c|c|c|c|c|c|c|c|}
\hline \multicolumn{2}{|c|}{ Unidades } & \multirow{2}{*}{$\begin{array}{c}\text { Emissor de } \\
\text { ruído }\end{array}$} & \multirow{2}{*}{ Materiais } & \multicolumn{2}{|c|}{ Ambientes } & \multicolumn{2}{c|}{$\begin{array}{c}\text { Resultados com } \\
\text { revestimento } \\
\text { dB(A) }\end{array}$} \\
\cline { 5 - 9 } Emissora & Receptora & & & Emissor & Receptor & $L_{A e q, n T}$ & $L_{A S m a x . n T}$ \\
\hline \multirow{2}{*}{ AP 81 } & \multirow{2}{*}{ AP 71 } & Descarga & $\begin{array}{c}\text { Materiais } \\
5+6\end{array}$ & Banheiro 5 & Banh. Hóspede & $\mathbf{4 3}$ & $\mathbf{4 7}$ \\
\cline { 4 - 9 } & & Descarga & Material 4 & Banheiro 5 & Banh. Hóspede & $\mathbf{4 8}$ & $\mathbf{5 2}$ \\
\hline
\end{tabular}

As tubulações sem revestimento foram medidas para o $L_{\text {Aeq }}$, que resultou em $55 \mathrm{~dB}(\mathrm{~A})$. Já nos resultados encontrados nas mesmas tubulações com revestimento dos materiais 5 e 6 o $L_{A e q}$, passou para $43 \mathrm{~dB}(\mathrm{~A})$ e, revestido com o material 4, o $L_{A e q}$, foi de $48 \mathrm{~dB}(\mathrm{~A})$, chegando a uma melhora nos níveis de ruídos de $12 \mathrm{~dB}(\mathrm{~A})$ e $7 \mathrm{~dB}(\mathrm{~A})$, respectivamente.

Os resultados do $L_{A S m a x}$ dos ensaios realizados para a válvula de descarga, mostram que nenhum dos dois atendem ao que é considerado desempenho mínimo na norma 15575-6 (ABNT, 2013).

\section{CONCLUSÃO}

Os resultados encontrados nos Ensaios A e B, em que foram aplicados materiais diferentes, mostram que a utilização dos materiais 1 e 2 para o envelopamento das tubulações tem um melhor desempenho nas faixas de frequência de maior sensibilidade ao ouvido humano, particularmente na faixa de $500 \mathrm{~Hz}$, conforme valores obtidos em $\mathrm{L}_{\mathrm{Aeq}} \mathrm{de} 33,2 \mathrm{~dB}(\mathrm{~A})$ para o Ensaio A; e $\mathrm{L}_{\mathrm{Aeq}}$ de 39,2 $\mathrm{dB}(\mathrm{A})$ para o Ensaio B. A diferença entre as faixas $\mathrm{L}_{\mathrm{Aeq}}$ ficou em $6 \mathrm{~dB}(\mathrm{~A})$, mostrando que os materiais 1 e 2, atendem melhor aos resultados determinados pela norma 15575-6 (ABNT, 2013), que explicita um desempenho mínimo de $\leq 37 \mathrm{~dB}(\mathrm{~A})$.

Conclui-se que, a partir da norma 15575-6 (ABNT, 2013), para que as tubulações hidráulicas sanitárias atendam aos valores de desempenho mínimo, intermediário e máximo, todas elas devem receber materiais que absorvam e atenuem os ruídos, antes da colocação dos forros programados para os ambientes. Caso o material aplicado não atinja os resultados esperados, uma melhora pode ser obtida com a inclusão de forro de gesso acartonado, com a possibilidade de acrescentar mantas de lã de vidro ou rocha, para a obtenção dos resultados necessários.

\section{REFERÊNCIAS}

NBR 10152: Níveis de ruído para conforto acústico. Rio de Janeiro, 1987, 4 p. Versão corrigida 1992.

NBR 15575-6: desempenho de edifícios habitacionais de até cinco pavimentos - parte 6: instalações hidrossanitárias. Rio de Janeiro, 2013. 31 p.

ISO. ISO 16032 Acoustics - Measurement of sound pressure level from service equipment in buildings. Engineering method. 2004.

LIMA, Kelly Ramos de; DOURADO, Janaina Borges; OLIVEIRA, Larissa Barbara de. Estudo Comparativo de Sistemas de Redução de Ruídos em Tubulações de Esgoto. 2012. 113 f. TCC (Pós Graduação) - Curso de Patologia na Construção Civil, Pós Graduação, Instituto Idd, Sao Paulo, 2012.

PAVANELLO, L. R. Investigação de ruído gerado por instalações hidrossanitárias em um edificação multifamiliar. 2014. 149 f. Dissertação (Mestrado em Engenharia Civil). Universidade Federal de Santa Maria, Centro de Tecnologia, Santa Maria, RS, 2014.

MATEUS, D. M. R. Acústica de Edifícios e Controle de Ruídos: Acústica de Edifícios e Controle de Ruídos. 2008. Material para aula da Universidade de Coimbra, Professor Auxiliar. Disponível em: <http://paginas.fe.up.pt/ earpe/conteudos/ARE/Apontamentosdadisciplina.pdf>. Acesso em: 23 jul. 2016. 